\title{
Induction of antioxidant and detoxifying enzymes by oriental bezoar
}

\author{
Tomoe Tsubonoya, Eiji Inoue, Yasuharu Shimizu, and Keiichi Sudo \\ Tokyo Research Center, Kyushin Pharmaceutical Co, Ltd. \\ 1-22-10, Wada, Suginami-ku, Tokyo 166-0012, Japan
}

Numbers of pages: 12

Numbers of figures: 4

Manuscript Type: Original Papers

Corresponding author: Tomoe Tsubonoya

Author affiliation: Tokyo Research Center, Kyushin Pharmaceutical Co, Ltd.

Address: 1-22-10, Wada, Suginami-ku, Tokyo 166-0012, Japan

Tel.: +81-3-5385-3211

Fax: $+81-3-5385-3219$

E-mail address: t-tsubonoya@kyushin.co.jp 


\begin{abstract}
Oriental bezoar, a gallstone formed in the gall sac of Bos taurus Linné var. domesticus Gmelin (Bovidae), has been used as an antipyretic, sedative, antispasmodic, and detoxifying drug in oriental medicine. It reportedly has an antioxidative effect; however, its underlying mechanism remains unclear. Therefore, we investigated the effects of oriental bezoar and its main components on the nuclear factor erythroid 2-related factor 2 (Nrf2)-antioxidant response element (ARE) pathway, which transcriptionally regulates the gene encoding an antioxidant enzyme, heme oxygenase-1 (HO-1), and detoxifying enzymes glutathione-S-transferase alpha 1 (GSTA1) and quinone oxidoreductase 1 (NQO1) in vitro. Using a dual-luciferase reporter assay and real-time PCR, oriental bezoar and its main constituent bilirubin were shown to induce ARE activity and up-regulate the expression of $\mathrm{HO}-1, \mathrm{GSTA1}$, and $\mathrm{NQO1}$ in HepG2 cells in a dose-dependent manner. These results suggest that activation of the Nrf2-ARE pathway is partially involved in the antioxidative effect of oriental bezoar, thus providing a scientific basis for oriental bezoar's traditional use for detoxification.
\end{abstract}

Keywords: Oriental bezoar, Nrf2-ARE, antioxidant, detoxification, bilirubin 


\section{Introduction}

Oriental bezoar is a gallstone formed in the gall sac of Bos taurus Linné var. domesticus Gmelin (Bovidae) and has been used as an antipyretic, sedative, antispasmodic, and detoxifying drug in oriental medicine ${ }^{1,2)}$. It contains bilirubin, biliverdin, bile acids, and amino acids ${ }^{1,2)}$. Among these ingredients, bilirubin and biliverdin are reported to have direct ${ }^{3)}$ and indirect ${ }^{4)}$ antioxidative effect. According to our previous papers ${ }^{5-7)}$, Reiousan $^{\circledR}$, a crude drug preparation consisting of oriental bezoar and ginseng, showed an antioxidative activity and facilitated the excretion of foreign substances in vivo. Reiousan's effects were attributed to a cooperative effect of oriental bezoar and ginseng; however, the underlying mechanism of oriental bezoar's antioxidative activity remains unclear.

The nuclear factor erythroid 2-related factor 2 (Nrf2)-antioxidant response element (ARE) pathway plays a role in the biological defense against oxidative stress and foreign substances ${ }^{8)}$. Upon exposure to oxidative stress and foreign substances, Nrf2 translocates from the cytoplasm to the nucleus and binds to the ARE to transcriptionally activate the genes encoding antioxidant enzymes, such as heme oxygenase-1 (HO-1), $\gamma$-glutamyl cysteine ligase, thioredoxin reductase-1, superoxide dismutase, glutathione peroxidase, and catalase, and detoxifying enzymes, such as glutathione-S-transferase alpha 1 (GSTA1), quinone oxidoreductase-1 (NQO1), and UDP-glucuronosyltransferase ${ }^{8)}$. Although the Nrf2-ARE pathway is vital for maintaining homeostasis of the body ${ }^{8-11)}$, Nrf2 levels are reported to decline in aging animals ${ }^{12,13)}$. Therefore, activating the Nrf2-ARE pathway has been considered a strategy to develop drugs for preventing various diseases caused by oxidative stress and foreign substances ${ }^{8-11)}$.

In this study, we investigated the effects of oriental bezoar and its constituents on the Nrf2-ARE pathway, which is involved in antioxidation and detoxification, using HepG2 cell culture. 


\section{Materials}

\section{Cells}

HepG2 cells (RIKEN BioResource Research Center, Ibaraki, Japan) were stored in liquid nitrogen. Cells with a passage number of 1 to 12 were used.

\section{Test Drugs}

Oriental bezoars obtained in Brazil (Kanai Shoten, Tokyo, Japan and Miyachu, Osaka, Japan) were mixed and pulverized in our manufacturing department (Kyushin Pharmaceuticals, Tokyo, Japan). The powdered oriental bezoar was suspended in 10\% dimethyl sulfoxide (DMSO, FUJIFILM Wako Pure Chemicals, Osaka, Japan), and extracted using an ultrasonic generator (Model 2510, Branson ultrasonics, CT, USA) for $30 \mathrm{~min}$ at $25^{\circ} \mathrm{C}$. The extract was sterilized by filtration using a $0.2-\mu \mathrm{m}$ membrane filter (ADVANTEC, Tokyo, Japan).

Bilirubin, R, S-sulforaphane (FUJIFILM Wako Pure Chemicals), cholic acid (Tokyo Chemical Industry, Tokyo, Japan), deoxycholic acid (Sigma-Aldrich, MO, USA), and hemin (Alfa Aesar, UK) were dissolved in DMSO. The DMSO concentration in the medium was set at $0.1 \%$.

\section{Chemicals}

Phosphate-buffered saline (PBS (-)), RPMI 1640 medium (FUJIFILM Wako Pure Chemicals), fetal bovine serum (FBS), $2.5 \%$ trypsin (Thermo Fisher Scientific, MA, USA), penicillin-streptomycin (Sigma-Aldrich), and Bambanker ${ }^{\circledR}$ (GC LYMPHOTEC, Tokyo, Japan) were used for cell culture.

For luciferase assays, tris (hydroxymethyl) aminomethane (Tris) (FUJIFILM Wako Pure Chemicals), Opti-MEM ${ }^{\circledR}$ I Reduced Serum Medium (Thermo Fisher Scientific), MultiFectam, plasmid DNA, Nano-Glo ${ }^{\circledR}$ Dual-Luciferase ${ }^{\circledR}$ Reporter Assay (Promega, WI, USA), and hydrochloric acid ( $\mathrm{HCl})$ (Yoneyama Yakuhin Kogyo, Osaka, Japan) were used with the target vector pGL4.37 [luc2P/ARE/Hygro] and internal control vector pNL1.1.PGK (phosphoglycerate kinase) 
[Nluc/PGK].

For RT-PCR, TRIzol ${ }^{\circledR}$ (Invitrogen, MA, USA), chloroform, isopropyl alcohol (Yoneyama Yakuhin

Kogyo), ethanol (FUJIFILM Wako Pure Chemicals), Otsuka distilled water (Otsuka Pharmaceuticals, Tokyo, Japan), $5 \times$ PrimeScriptTM RT Master Mix, TB Green ${ }^{\circledR}$ Premix Ex Taq ${ }^{\mathrm{TM}}$ (Tli RNaseH Plus)

$(2 \times)$, and PCR primers for $H O-1$ (forward 5'-TTGCCAGTGCCACCAAGTTC-3' and reverse

5'-TCAGCAGCTCCTGCAACTCC-3'), NQO1 (5'-GGATTGGACCGAGCTGGAA-3' and

5'-GAAACACCCAGCCGTCAGCTA-3') and GSTAl (5'-TCTGCCCGTATGTCCACCTG-3' and

5'-TGCCAACAAGGTAGTCTTGTCCA-3'), and GAPDH (Glyceraldehyde 3-phosphate

dehydrogenase) (5'-GCACCGTCAAGGCTGAGAAC-3' and 5'-TGGTGAAGACGCCAGTGGA-3')

(Takara Bio, Shiga, Japan) were used.

\section{Methods}

\section{Cell culture}

HepG2 cells were cultured in RPMI 1640 medium supplemented with $10 \%$ of inactivated FBS, $100 \mathrm{U} / \mathrm{mL}$ penicillin, and $100 \mu \mathrm{g} / \mathrm{mL}$ streptomycin in a $\mathrm{CO}_{2}$ incubator (SANYO, Tokyo, Japan) at $37^{\circ} \mathrm{C}$ and $5 \% \mathrm{CO}_{2}$. The culture medium was replaced once every 3 to 4 days.

\section{Transfection}

The cells were cultured in 96-well white plates at a density of $2 \times 10^{4}$ cells in $0.1 \mathrm{~mL}$ per well for 24 h. Tris-HCl buffer $(20 \mathrm{mM}, \mathrm{pH} 7.4,50 \mu \mathrm{L}), 0.5 \mu \mathrm{g}$ of a target vector pGL4.37 [luc2P/ARE/Hygro], and control vector pNL1.1.PGK [Nluc/PGK] were added to a microtube. Then, $25 \mu \mathrm{L}$ of MultiFectam was added, mixed, and incubated at room temperature for 30 min. Opti-MEM ${ }^{\circledR}$ I Reduced Serum Medium $(25 \mu \mathrm{L})$ was added, mixed, and incubated at room temperature for 5 min. Lastly, $10 \mu \mathrm{L}$ of the mixture solution was added to the medium and incubated for $4 \mathrm{~h}$.

\section{Reporter $\operatorname{assay}^{14)}$}

The transfected cells were treated with a fresh medium containing a test drug for $18 \mathrm{~h}$. After 
removing the medium, $80 \mu \mathrm{L}$ of FBS- and phenol red-free RPMI 1640 medium and $80 \mu \mathrm{L}$ of One-Glo ${ }^{\mathrm{TM}}$ reagent were added to each well. After the microplate was shaken orbitally for 3 min, the luminescence due to activation of firefly luciferase (Fluc) was measured using a microplate reader (Synergy H1, Biotek, VT, USA). Then, $80 \mu \mathrm{L}$ of Stop \& Glo ${ }^{\circledR}$ reagent was added to each well and shaken orbitally for $3 \mathrm{~min}$. After just $7 \mathrm{~min}$, the luminescence due to activation of Nanoluc ${ }^{\circledR}$ luciferase (Nluc), an internal control was measured. The relative light unit (RLU) of Fluc was corrected by the RLU of Nluc (Fluc RLU/Nluc RLU). The relative luciferase activity was calculated as the ratio of the corrected RLU of the treatment groups to the RLU of the control group, and it was shown as the ARE promoter activity.

\section{RNA extraction ${ }^{15)}$}

The cells were cultured in a 48 -well plate at a density of $8 \times 10^{4}$ cells in $0.4 \mathrm{~mL}$ per well for $24 \mathrm{~h}$. The medium was replaced with a fresh medium containing the test drug and incubated for $6 \mathrm{~h}$ for HO- 1 RNA extraction or $18 \mathrm{~h}$ for GSTAl and NQOI RNA extraction. After removing the medium, $0.2 \mathrm{~mL}$ of TRIzol ${ }^{\circledR}$ was added to the cells. The cells were then scraped with a pipette tip from the plate to disrupt cell membranes, left for $5 \mathrm{~min}$ at room temperature, and collected in a microtube. Then, 40 $\mu \mathrm{L}$ of chloroform was added to shake vigorously and stirred. After $5 \mathrm{~min}$, each sample was centrifuged at $12,000 \times \mathrm{g}$ at $4^{\circ} \mathrm{C}$ for $15 \mathrm{~min}$. From the aqueous layer, $50 \mu \mathrm{L}$ was transferred to a new microtube. Then, $70 \mu \mathrm{L}$ of isopropyl alcohol was added and stirred. After $10 \mathrm{~min}$, each sample was centrifuged at $12,000 \times \mathrm{g}$ at $4^{\circ} \mathrm{C}$ for $10 \mathrm{~min}$. After removing the supernatant, $200 \mu \mathrm{L}$ of $75 \%$ ethanol was added and stirred. Each sample was centrifuged at 7,500 $\times \mathrm{g}$ and $4{ }^{\circ} \mathrm{C}$ for $5 \mathrm{~min}$ before the supernatant was removed. The precipitates were air-dried for about $5 \mathrm{~min}$ and dissolved in $40 \mu \mathrm{L}$ of distilled water by stirring.

\section{RNA quantification and reverse transcription}

A $20 \mu \mathrm{L}$ RNA solution and $160 \mu \mathrm{L}$ of distilled water were added to each well of the UV-permeable 
96-well plate. After shaking for $10 \mathrm{~s}$, RNA concentration was measured at the absorbance of $260 \mathrm{~nm}$.

A $20-\mu \mathrm{L}$ reverse transcription reaction consisting of $2 \mu \mathrm{L}$ of $5 \times$ PrimeScript RT Master Mix, 0.5

$\mu \mathrm{g}$ of total RNA, and distilled water was conducted at $37^{\circ} \mathrm{C}$ for $15 \mathrm{~min}$ and $85^{\circ} \mathrm{C}$ for $5 \mathrm{~s}$ and then stored at $4^{\circ} \mathrm{C}$.

\section{Gene expression analysis ${ }^{16}$}

A $25-\mu \mathrm{L}$ real-time PCR consisted of $12.5 \mu \mathrm{L}$ of TB Green ${ }^{\circledR}$ Premix Ex Taq ${ }^{\mathrm{TM}}$ II, $0.2 \mu \mathrm{L}$ of $50 \mu \mathrm{M}$ forward primer, $0.2 \mu \mathrm{L}$ of $50 \mu \mathrm{M}$ reverse primer, less than $100 \mathrm{ng}$ of template DNA in $2.0 \mu \mathrm{L}$, and $10.1 \mu \mathrm{L}$ of distilled water. The PCR was conducted at $95^{\circ} \mathrm{C}$ for $30 \mathrm{~s}$ and 35 cycles of 2 -step PCR at $95^{\circ} \mathrm{C}$ for $5 \mathrm{~s}$ and $60^{\circ} \mathrm{C}$ for $30 \mathrm{~s}$.

The levels of mRNA of $H O-1, G S T A 1, N Q O 1$, and GAPDH were quantified by calculating the $\triangle \mathrm{Ct}$ and $\Delta \Delta \mathrm{Ct}$ values of each reaction using the following formulas:

$$
\begin{aligned}
& \Delta \mathrm{Ct}=[\mathrm{Ct}(\text { target gene })-\mathrm{Ct} \text { (internal control gene })] \\
& \Delta \Delta \mathrm{Ct}=[\Delta \mathrm{Ct}(\text { control group })-\Delta \mathrm{Ct}(\text { treatment group })] \\
& \text { mRNA expression }=2^{\Delta \Delta \mathrm{Ct}}
\end{aligned}
$$

The control group was the vehicle-treated group, and the treatment groups were the test drug or positive control-treatment group.

\section{Cytotoxicity assay}

HepG2 cells were cultured in a 96-well plate at a density of $1.3 \times 10^{4}$ cells in $0.1 \mathrm{~mL}$ per well for 18 $\mathrm{h}$. The medium was replaced with a fresh medium containing test drugs to incubate for $18 \mathrm{~h}$. The medium was then replaced with Cell Titer $96^{\circledR}$ six-fold diluted in a fresh medium. After $2 \mathrm{~h}$, cell viability was measured at the absorbance of $490 \mathrm{~nm}$.

\section{Statistical analysis}

The results were expressed as means \pm standard error. The significance of the differences in the data was estimated using the one-way analysis of variance followed by Dunnett's multiple range test. 
The differences with $\mathrm{P}<0.05$ were considered statistically significant.

\section{Results}

\section{Effects on ARE activity}

Oriental bezoar increased ARE activity in a dose-dependent manner, achieving a significant increase at $1000 \mu \mathrm{g} / \mathrm{mL}$. Bilirubin, a component of oriental bezoar, showed a tendency to increase ARE activity at $171 \mu \mathrm{M}(100 \mu \mathrm{g} / \mathrm{mL})$. On the other hand, sulforaphane increased ARE activity at 5 $\mu \mathrm{M}$ (Fig. 1).

\section{Effects on mRNA expression of antioxidant enzyme (HO-1) and detoxifying enzymes (GSTA1,} NQO1)

Oriental bezoar increased HO-l (Fig. 2A), GSTAl (Fig. 3A), and NQOl (Fig. 3B) expression in a dose-dependent manner, causing significant effects at 1000, 1000, and $3000 \mu \mathrm{g} / \mathrm{mL}$, respectively. Bilirubin also increased $\mathrm{HO}-1$ (Fig. 2B), GSTAl (Fig. 3A), and $N Q O 1$ (Fig. 3B) expression; bilirubin's effect on $\mathrm{HO}-1$ expression was significant at $100 \mu \mathrm{M}(100 \mu \mathrm{g} / \mathrm{mL}$, Fig. 2B). On the other hand, deoxycholic and cholic acid did not affect $\mathrm{HO}-\mathrm{l}$ expression (Fig. 2B). On the other hand, hemin increased $\mathrm{HO}-1$ expression at $20 \mu \mathrm{M}$ (Fig. 2A, 2B), and sulforaphane increased GSTAl (Fig. 3A) and $N Q O 1$ (Fig. 3B) expression at $5 \mu \mathrm{M}$.

\section{Cytotoxicity}

Oriental bezoar and bilirubin did not exhibit cytotoxicity at $1000 \mu \mathrm{g} / \mathrm{mL}$ and $171 \mu \mathrm{M}(100 \mu \mathrm{g} / \mathrm{mL})$, respectively (Fig. 4).

\section{Discussion}

Oriental bezoar and bilirubin increased ARE activity and the expression of $H O-1, G S T A 1$, and NQO1. HO-1 is an inducible antioxidant enzyme and is involved in the degradation of heme into 
biliverdin, carbon monoxide $(\mathrm{CO})$, and free iron $^{17)}$. Biliverdin is reduced to bilirubin by biliverdin reductase $^{17)}$. Bilirubin and biliverdin have an antioxidative effect, and CO has an anti-inflammatory effect $^{18)}$. Hence, $H O-1$ induction may suppress oxidative stress-induced cell injury ${ }^{18)}$. GSTA1 and NQO1 are known to act as detoxifying enzymes ${ }^{19)}$, with GSTA1 catalyzing glutathione conjugation and NQO1 reducing quinones ${ }^{19)}$. These enzymes are involved in the metabolism of carcinogens, such as benzo[a]pyrene and aflatoxin, which are metabolically activated by phase I metabolic reactions; therefore, their induction may decrease carcinogens in the body ${ }^{11,20)}$. The activation of the Nrf2-ARE pathway was also reported to induce many other antioxidant enzymes, such as $\gamma$-glutamyl cysteine ligase, thioredoxin reductase-1, superoxide dismutase, glutathione peroxidase, and catalase, and detoxifying enzymes such as UDP-glucuronosyltransferase ${ }^{8,21,22)}$. These findings suggest that oriental bezoar has antioxidative and detoxifying effects by inducing these enzymes by activating the Nrf2-ARE pathway.

Oriental bezoar contains bilirubin, biliverdin, bile acids such as deoxycholic and cholic acid, and amino acids $^{1,2)}$. In this study, bilirubin showed a similar enhancing effect as oriental bezoar on HO-1, GSTA1, and NQOI expression. On the other hand, bile acids did not affect $\mathrm{HO}-1$ expression. Bilirubin was reported to increase HO-1 protein levels in $\mathrm{H} 9 \mathrm{c} 2$ cells derived from a rat heart ${ }^{4}$. These findings suggest that the activating effect of oriental bezoar on the Nrf2-ARE pathway is partially attributed to bilirubin.

On the other hand, oriental bezoar did not exhibit cytotoxicity on HepG2 cells even at the concentration sufficient for activating the Nrf2-ARE pathway. These data suggest that oriental bezoar can enhance the biological defense without causing cell damage.

In summary, we have shown that oriental bezoar and its component bilirubin induce ARE activity and increase the expression of HO-1, GSTA1, and NQO1, the downstream genes of the Nrf2-ARE pathway. Although our results are in vitro and require further confirmation, they may help delineate 
the antioxidative and detoxifying effects of oriental bezoar.

\section{Conflict of interest}

This research was supported by Kyushin Pharmaceuticals. The authors declare no conflicts of interest.

\section{References}

1. (1985) Bezoar. Dictionary of Chinese Materia Medica, Shang-Hai-Ke-Xue-Ji-Shu-Chu-Ban-She, Shogakukan, Tokyo. pp 787-790. Japanese.

2. Kariyone T (1971) [Japanese and Chinese herbal medicine]. Hirokawa Publishing, Tokyo. pp 327. Japanese.

3. Stocker R, Yamamoto Y, McDonagh AF, Glazer AN, Ames BN (1987) Bilirubin is an antioxidant of possible physiological importance. Science 27:1043-1046.

4. Kim DS, Chae SW, Kim HR, Chae HJ (2009) CO and bilirubin inhibit doxorubicin-induced cardiac cell death. Immunopharmacol Immunotoxicol 31:64-70.

5. Morishita S, Saito T, Shoji M, Hirai Y, Tanaka Y (1988) Pharmacological studies of "Reiousan" which contains, bezoar and ginseng. Folia Pharmacol Jpn 91:129-140. Japanese.

6. Morishita S, Saito T, Shoji M, Tanaka A, Saeki K, Ito C (1989) Pharmacological effects of Reiousan on experimental hepatic injuries and hepatic functions. Folia Pharmacol Jpn 93:261-270. Japanese.

7. Morishita S, Shoji M, Oguni Y, Sugimoto C, Hirai Y, Toma S, Ito C (1991) Pharmacological studies of Reiousan which contains bezoar and ginseng: III. Effects on experimental cerebral ischemia. Folia Pharmacol Jpn 98:435-442. Japanese.

8. Tonelli C, Chio IIC, Tuveson DA (2018) Transcriptional Regulation by Nrf2. Antioxid Redox 
Signal 29:1727-1745

9. Itoh K (2009) Disease regulation by Nrf2 antioxidant system. SEIKAGAKU 81:447-455. Japanese.

10. Motohashi H (2014) Contribution of Nrf2 to stress response and metabolic reprogramming in cell proliferation. SEIKAGAKU 86:269-273. Japanese.

11. Izumi Y (2018) Anti-inflammatory action of the transcription factor Nrf2. Folia Pharmacol Jpn 152:209. Japanese.

12. Suh JH, Shenvi SV, Dixon BM, Liu H, Jaiswal AK, Liu RM, Hagen TM (2004) Decline in transcriptional activity of Nrf2 causes age-related loss of glutathione synthesis, which is reversible with lipoic acid. Proc Natl Acad Sci USA 101:3381-3386.

13. Ungvari Z, Bailey-Downs L, Gautam T, Sosnowska D, Wang M, Monticone RE, Telljohann R, Pinto JT, de Cabo R, Sonntag WE, Lakatta EG, Csiszar A (2011) Age-associated vascular oxidative stress, Nrf2 dysfunction, and NF- $\kappa B$ activation in the nonhuman primate Macaca mulatta. J Gerontol A Biol Sci Med Sci 66:866-875.

14. TECHNICAL MANUAL, Nano-Glo ${ }^{\circledR}$ Dual-Luciferase ${ }^{\circledR}$ Reporter Assay System, Instructions for Use of Products N1610, N1620, N1630 and N1650. Promega.

15. TRIzol ${ }^{\circledR}$ reagent protocol Rev. date: 12 Jun 2007. Thermo Fisher.

16. [Real-time PCR for the first time 1710V3.0]. Takara Bio. Japanese.

17. Ryter SW, Alam J, Choi AM (2006) Heme oxygenase-1 / carbon monoxide: from basic science to therapeutic applications. Physiol Rev 86:583-650.

18. Takahashi T, Shimizu H, Inoue K, Morimatsu H, Umeda K, Omori E, Akagi R, Morita K (2007) Protective role of HO-1 in oxidative tissue injuries. Folia Pharmacol Jpn 130:252-256. Japanese.

19. Itoh K, Ebina M (2012) Intracellular Signaling Cascade for the Protection Against Oxidative Stress: Nrf2 / Keap1 System. KAGAKU TO SEIBUTSU 50:423-429. Japanese. 
20. Garg R, Gupta S, Maru GB (2008) Dietary curcumin modulates transcriptional regulators of phase I and phase II enzymes in benzo[a]pyrene-treated mice: mechanism of its anti-initiating action. Carcinogenesis 29:1022-1032

21. Suzuki T, Yamamoto M (2006) [Response mechanism of redox signal by Keap1-Nrf2 system.] Experimental Medicine 24:1737-1743. Japanese.

22. Nguyen T, Sherratt PJ, Pickett CB (2003) Regulatory mechanisms controlling gene expression mediated by the antioxidant response element. Annu Rev Pharmacol Toxicol 43:233-260. 


\section{Figure Legends}

Fig. 1 Oriental bezoar and bilirubin activated the ARE promoter activity

Data are expressed as mean \pm SEM $(\mathrm{N}=5)$. *: $\mathrm{P}<0.05$, compared to the control group using Dunnett's test.

Fig. 2 Oriental bezoar and bilirubin increased the expression of $\mathrm{HO}-1$ in HepG2 cells

(A) The effect of oriental bezoar on $\mathrm{HO}-1$ expression.

(B) The effect of bilirubin, deoxycholic acid, and cholic acid on $\mathrm{HO}-1$ expression.

Data are expressed as mean \pm SEM $(\mathrm{N}=3-4)$. **: $\mathrm{P}<0.01, *$ : $\mathrm{P}<0.05$, compared to the control group using Dunnett's test.

Fig. 3 Oriental bezoar and bilirubin increased the expression of GSTA1 and NQO1

(A) The effect of oriental bezoar, bilirubin, and sulforaphane on GSTA1 expression in HepG2 cells.

(B) The effect of oriental bezoar, bilirubin, and sulforaphane on NQO1 expression in HepG2 cells. Data are expressed as mean \pm SEM $(\mathrm{N}=3-4)$. **: $\mathrm{P}<0.01, *$ : $\mathrm{P}<0.05$, compared to the control group using Dunnett's test.

Fig. 4 Oriental bezoar and bilirubin did not show cytotoxicity in HepG2 cells Data are expressed as mean \pm SEM $(\mathrm{N}=3)$. 
bioRxiv preprint doi: https://doi.org/10.1101/2021.01 25.428174 this version posted January 27,2021 . The copyright holder for this preprint (which was not certified by peer review) is the author/funder, who has granted bioRxiv a license to display the preprint in perpetuity. It is made available under aCC-BY-NC-ND 4.0 International license.

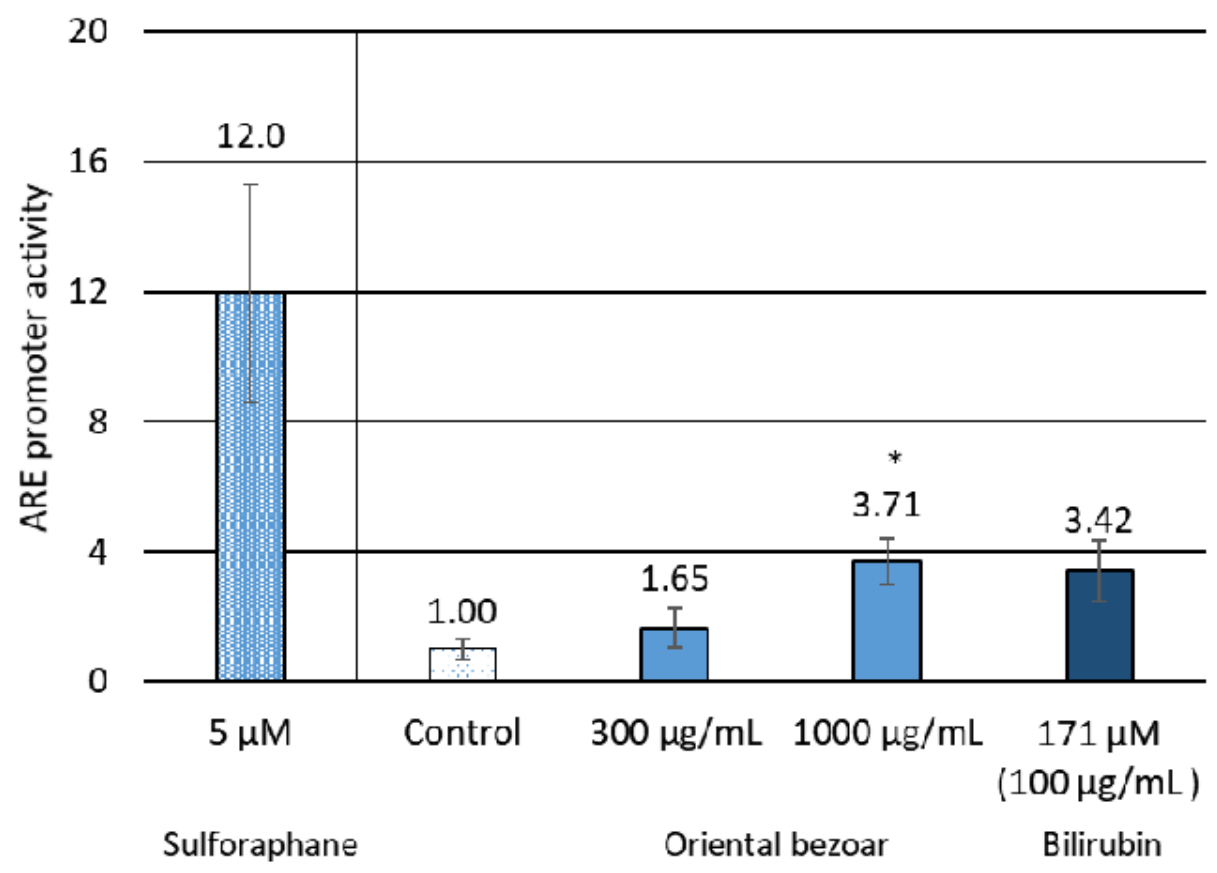

Fig. 1 
bioRxiv preprint doi: https://doi.org/10.1101/2021.01.25.428174 this version posted January 27, 2021. The copyright holder for this preprint (which was not certified by peer review) is the author/funder, who has granted bioRxiv a license to display the preprint in perpetuity. It is made available under aCC-BY-NC-ND 4.0 International license.

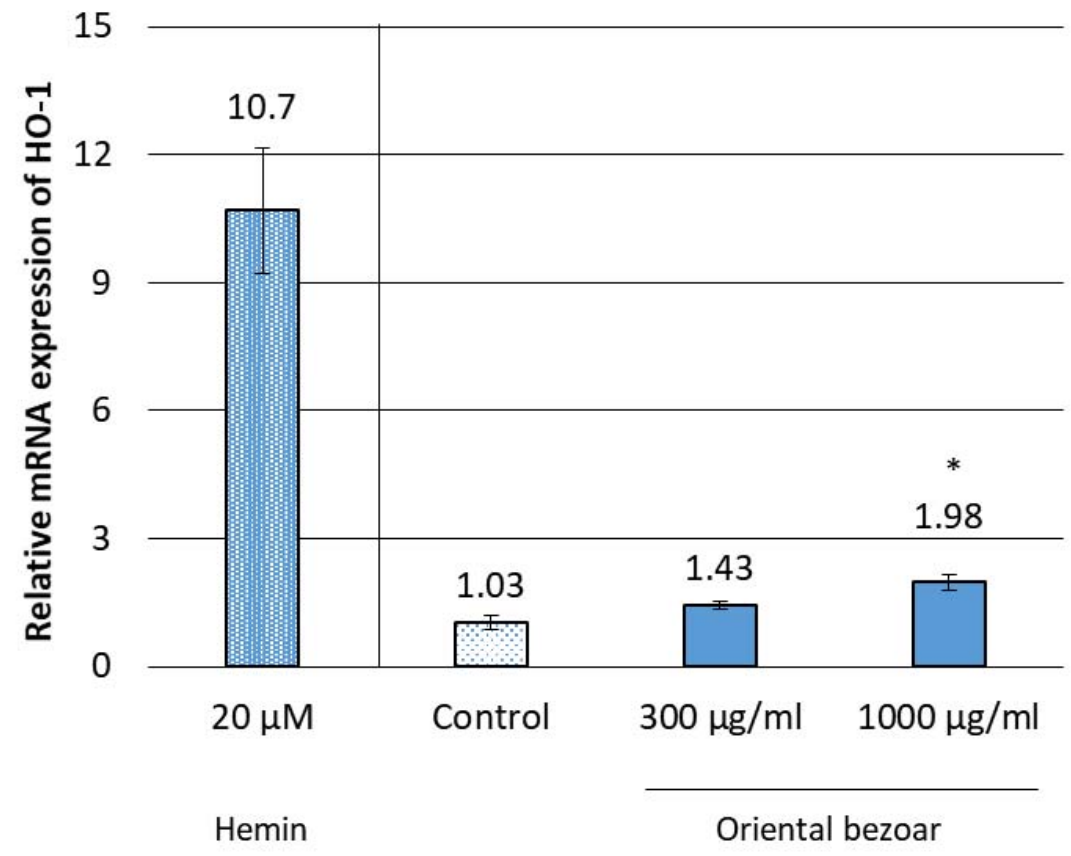

Fig. 2 (A) 
bioRxiv preprint doi: https://doi.org/10.1101/2021.01.25.428174; this version posted January 27,2021 . The copyright holder for this preprint (which was not certified by peer review) is the author/funder, who has granted bioRxiv a license to display the preprint in perpetuity. It is made available under aCC-BY-NC-ND 4.0 International license.

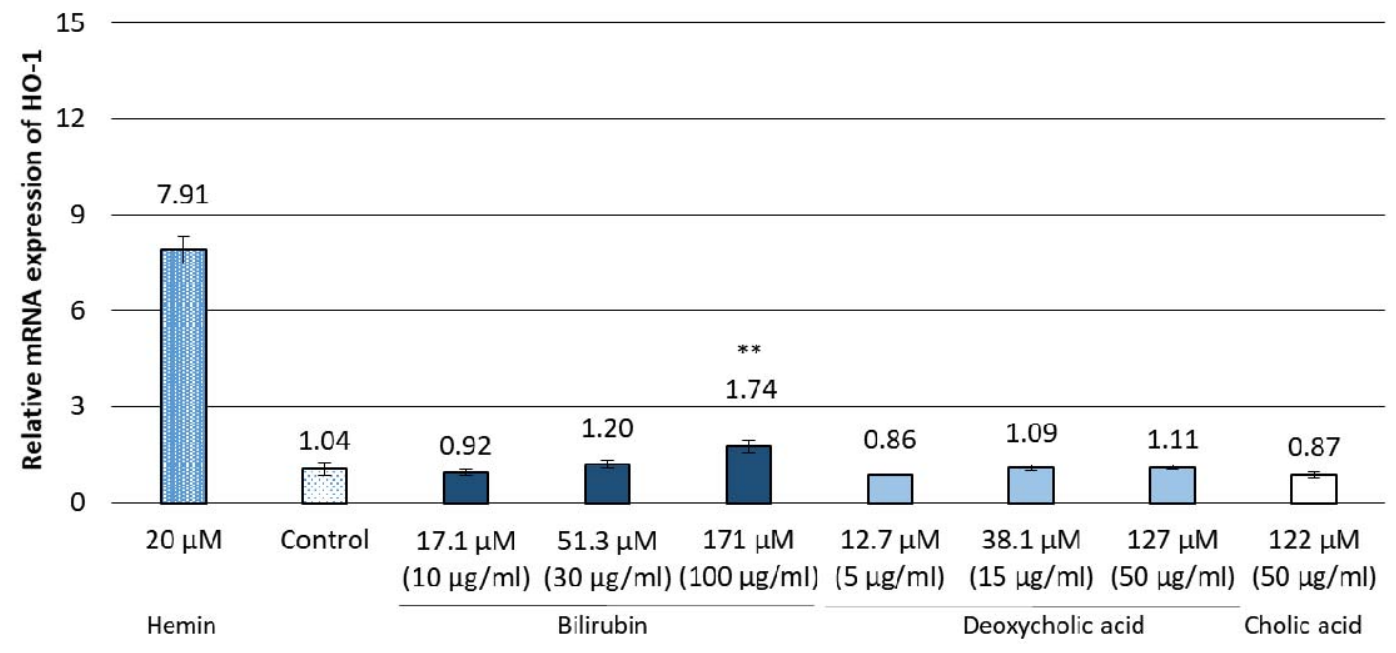

Fig. 2 (B) 
bioRxiv preprint doi: https://doi.org/10.1101/2021 01.25.428174 - this version posted January 27, 2021. The copyright holder for this preprint (which was not certified by peer review) is the author/funder, who has granted bioRxiv a license to display the preprint in perpetuity. It is made available under aCC-BY-NC-ND 4.0 International license.

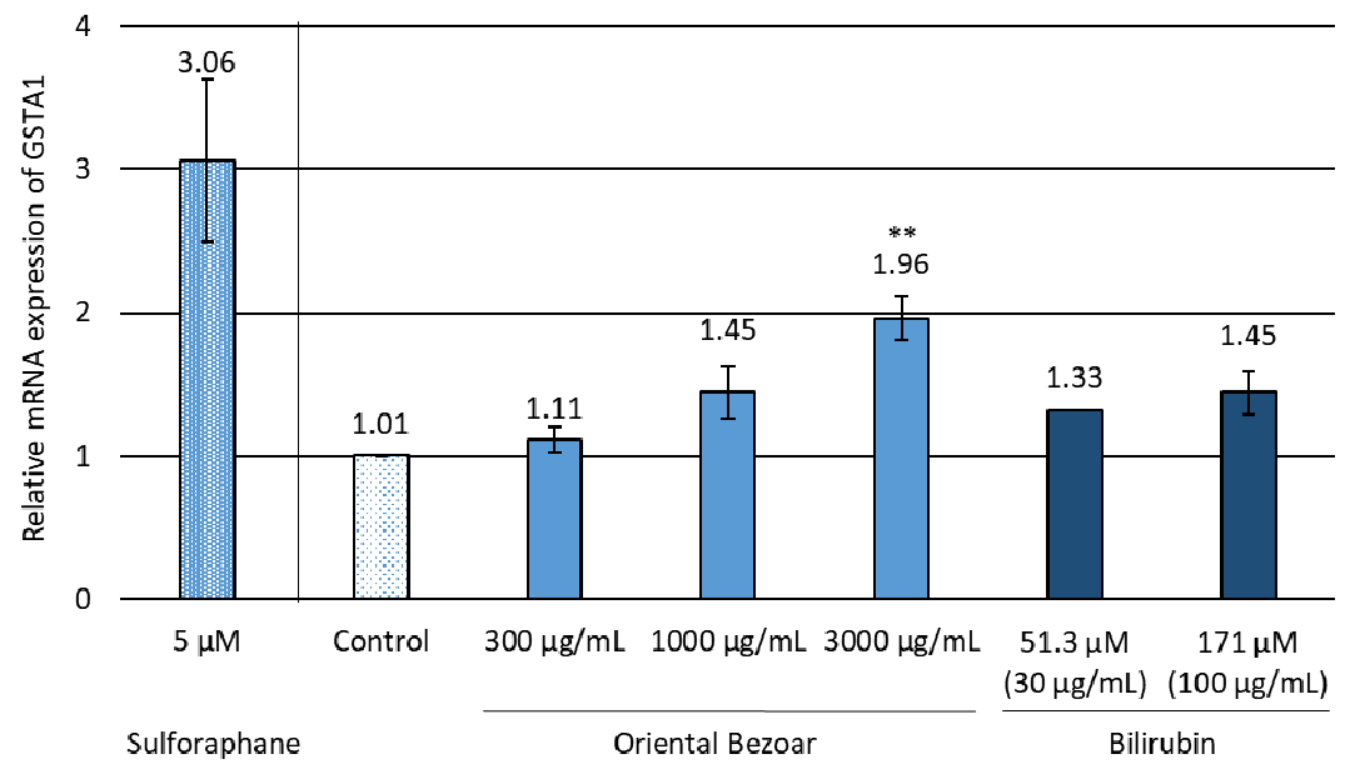

Fig. 3 (A) 
bioRxiv preprint doi: https://doi.org/10.1101/2021.01.25.428174 this version posted January 27, 2021. The copyright holder for this preprint (which was not certified by peer review) is the author/funder, who has granted bioRxiv a license to display the preprint in perpetuity. It is made available under aCC-BY-NC-ND 4.0 International license.

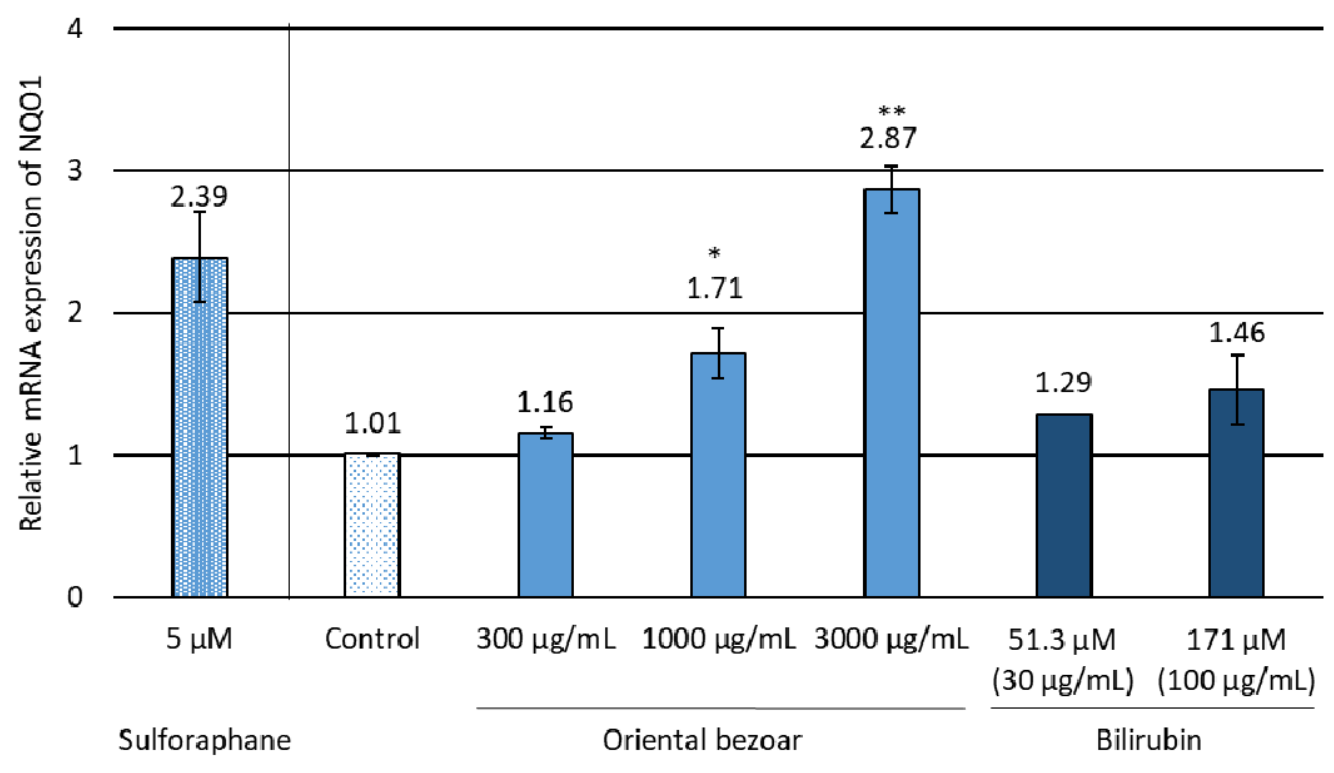

Fig. 3 (B) 
bioRxiv preprint doi: https://doi.org/10.1101/2021.01.25.428174 this version posted January 27,2021 . The copyright holder for this preprint (which was not certified by peer review) is the author/funder, who has granted bioRxiv a license to display the preprint in perpetuity. It is made available under aCC-BY-NC-ND 4.0 International license.

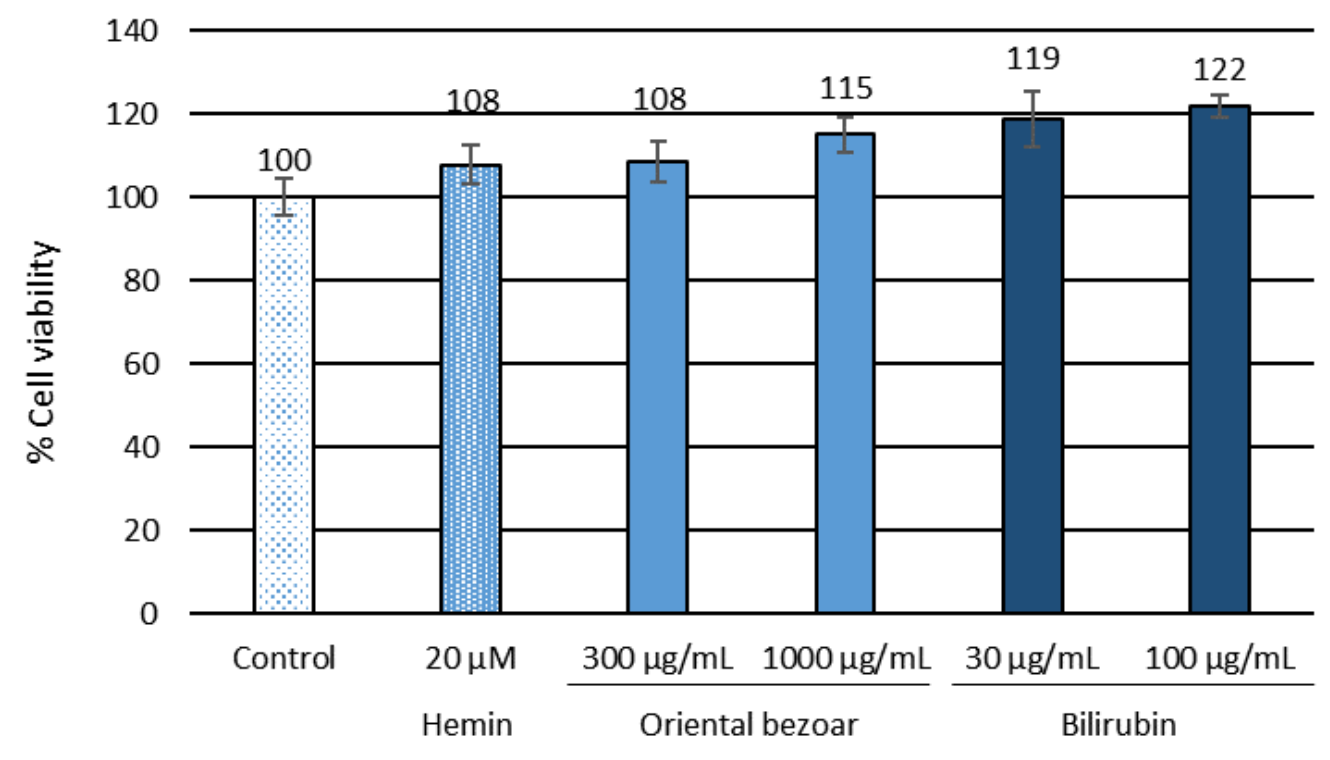

Fig. 4 